\title{
Fluid Overload in Children with Severe Sepsis and Septic Shock
}

\author{
Copana Raul ${ }^{1,2, *}$, Diaz Willmer ${ }^{3}$ \\ ${ }^{1}$ Pediatric Intensive Care Department, Manuel Ascencio Villarroel Children's Hospital, Cochabamba, Bolivia \\ ${ }^{2}$ Maternoinfantile Health Department, Medicine Faculty, San Simon University, Cochabamba, Bolivia \\ ${ }^{3}$ Pediatric Intensive Care Department, Ovidio Aliaga Uria Chidren's Hospital, La Paz, Bolivia
}

\section{Email address:}

dr_copana_raul@yahoo.com (C. Raul)

${ }^{*}$ Corresponding author

\section{To cite this article:}

Copana Raul, Diaz Willmer. Fluid Overload in Children with Severe Sepsis and Septic Shock. American Journal of Pediatrics. Vol. 5, No. 4, 2019, pp. 299-303. doi: 10.11648/j.ajp.20190504.33

Received: Octorber 17, 2019; Accepted: December 20, 2019; Published: December 31, 2019

\begin{abstract}
Fluid therapy is one pillar of the treatment of septic shock, however, a hydric $\geq 10 \%$ of the weight or Fluid Overload (FO $>10 \%)$ is associated with poor hospital outcomes. The present study aims to determine the FO in patients with septic shock, and its main associations in terms of mortality and morbidity. An observational and descriptive study was conducted in 49 hospitalized children with septic shock in the PICU of the Manuel Ascencio Villarroel Children's Hospital (MAVCH); The patients were divided into two groups according to the $\mathrm{FO}>10 \%$ (22 patients) and $<10 \%$ (18 patients), for their descriptive analysis we included comparison of means and calculation of the OR. Regarding the water requirements, we observed that the group with $\mathrm{FO}>10 \%$ a mean of $5681 \mathrm{ml}$; while in the group with $\mathrm{ISCH}<10 \%$ the mean was $3297.8 \mathrm{ml}(\mathrm{p}=0.19)$ during first 72 hours, showing greater overload with the administration of colloids and blood products $(\mathrm{p}=0.02, \mathrm{p}=0.004)$. Regarding hospital outcomes, was found morbidity associated with $\mathrm{FO}>10 \%$ (respiratory dysfunction, vasopressor requirement and renal replacement therapy); The length of hospitalization and FO were not different in groups $(\mathrm{p}=0.60)$, but there was higher mortality of patients with FO $>10 \%$ ( $p=0.01$, OR: 5.57 IC95\% 1.4-21.8). Fluids therapy of in the patient with septic shock constitutes one of the first-line hemodynamic treatments, however in limited resources settings, overload should be avoided, mainly due to associated morbidity during the first 72 hours.
\end{abstract}

Keywords: Fluid Overload, Sepsis, Septic Shock, Fluid Therapy

\section{Introduction}

The incidence of severe sepsis and septic shock varies between 20 and $30 \%$ in most pediatric intensive care units (PICU) and is one of the leading causes of mortality. [1]

One of the pillars of septic shock treatment is fluid therapy to increase systolic volume and, thus, the patient's cardiac output as an initial resuscitation measure. [2-4] However, the balance of fluids provided $\geq 10 \%$ of body weight or Fluid Overload (FO) is associated with organic dysfunction, mortality, stay in PICU, duration of Mechanical Ventilation (MV) and use of Renal Replacement Therapy (RRT). [5-8]

This research will provide knowledge regarding fluid therapy in children with septic shock, filling the void that exists regarding FO and its possible negative effects present in our patients. Therefore, the present study sought to determine the FO in patients with septic shock admitted to the PICU of the Manuel Ascencio Villarroel Children's Hospital (MAVCH), and its main associations based on mortality and hospital stay.

\section{Methods}

An observational and descriptive study was conducted in 49 children hospitalized with septic shock in the MAVCH PICU, using a randomized sampling of all admissions, a sample size of 50 patients was calculated for this purpose; excluding those with congenital heart disease, known kidney or liver disease, those resuscitated with fluids or vasopressor therapy outside the hospital and those who died before 72 hours of admission. The patients were divided into 2 groups 
according to the $\mathrm{FO}>10 \%$ or $<10 \%$ for later analysis.

The FO was established according to the following formula: Fluid overload index $=($ (total of liquids administrated - total of eliminated liquid) / body weight of entry $\mathrm{x} 100$ ), assuming as a cut-off point the $\mathrm{FO}>10 \%$ registered until the third day of hospitalization in the FO. The score of the Pediatric Logistic Organic Dysfunction Score (PELODS) was determined according to pre-established values. It was established on the 3rd day of the study, which was compared with the water overload index, to see the relationship of organic dysfunction.

In the statistical analysis, version 23.0 of the SPSS Statistics ${ }^{\circledR}$ program was used. The descriptive analysis included a comparison of means for the quantitative variables and percentages for the qualitative variables with the Chi square test and the Mann-Whitney U test. Determination of the normality of the sample using a t-student test.

\section{Results}

In 2016, 254 patients were admitted to PICU, 49 of them with septic shock, 9 were excluded due to the criteria of this study, with 40 remaining for the study, they were divided into 2 groups: $\mathrm{FO}>10 \% 22$ patients and 18 patients in $\mathrm{FO}<10 \%$ group, which were groups with comparable characteristics. See Table 1.

Table 1. Distribution by age, sex, infectious focus, comorbidities of the study groups Fluid overload $<$ and $>10 \%$.

\begin{tabular}{|c|c|c|c|}
\hline & & \multicolumn{2}{|c|}{ Fluid Overload Index } \\
\hline & & FO $>10 \%$ & FO $<10 \%$ \\
\hline \multirow{2}{*}{ Gender } & Male & $12(54,5 \%)$ & $10(55,6 \%)$ \\
\hline & Female & $10(45,5 \%)$ & $8(44,4 \%)$ \\
\hline \multirow{4}{*}{ Ege } & $<1$ year & $5(22,7 \%)$ & $9(50 \%)$ \\
\hline & 1 to 5 years & $9(40,9 \%)$ & $9(50 \%)$ \\
\hline & 6 to 9 years & $3(13,6 \%)$ & $0(0 \%)$ \\
\hline & 10 to 15 years & $5(22,7 \%)$ & $0(0 \%)$ \\
\hline \multirow{4}{*}{ Infectious source } & Soft tissues & $2(9,1 \%)$ & $0(0 \%)$ \\
\hline & Abdominal & $1(4,5 \%)$ & $4(22,2 \%)$ \\
\hline & Without focus & $5(22,7 \%)$ & $1(5,6 \%)$ \\
\hline & Nervous system & $0(\%)$ & $2(11,1 \%)$ \\
\hline \multirow{3}{*}{ Comorbilities } & None & $12(54,5 \%)$ & $15(83,3 \%)$ \\
\hline & Malnourishment & $5(22,7 \%)$ & $3(16,7 \%)$ \\
\hline & Oncohematologic & $4(18,2 \%)$ & $0(0 \%)$ \\
\hline
\end{tabular}

Regarding the administration of crystalloid, colloid and blood products solutions, they were administered (additional to basal requirements) a total volume of $1610 \mathrm{ml}$ to $7700 \mathrm{ml}$ (80 to $385 \mathrm{ml} / \mathrm{kg} / 24$ hours) with a mean of $2121 \mathrm{ml}(106$ $\mathrm{ml} / \mathrm{kg} / 24$ hours) in the $\mathrm{FO}>10 \%$ group and a volume of $312 \mathrm{ml}$ to $2949 \mathrm{ml}$ (16 to $147 \mathrm{ml} / \mathrm{kg} / 24$ hours) with a mean of $499 \mathrm{ml}$ (25ml/kg/24hour) in the $\mathrm{FO}<10 \%$ group. Being able to determine a significant relationship between the administration of crystalloid, colloid and blood products and $\mathrm{FO}(\mathrm{p}=0.004)$.

The $0.9 \%$ saline solution was administered in $85 \%(n=34)$ of the total patients and ringer lactate in $45 \%(n=18))$. A mean bolus of $891 \mathrm{ml}(45 \mathrm{ml} / \mathrm{kg})$ of $0.9 \%$ saline were administered in $\mathrm{FO}>10 \%$ group and $366 \mathrm{ml}(19 \mathrm{ml} / \mathrm{kg})$ in the $\mathrm{FO}<10 \%$ group. From ringer lactate, an average of $381.4 \mathrm{ml}$ in patients with $\mathrm{FO}>10 \%$ group, and $161 \mathrm{ml}$ in patients with $\mathrm{FO}<10 \%$, in relation to $\mathrm{FO}$ there is no statistically significant difference between both crystalloid solutions $(p=0.28)$. See table No 2. Colloid administration is observed in $65 \%(n=26)$ of patients; The albumin being $5 \%$ used in 25 patients and the jellies in 4 . In patients with $\mathrm{FO}>10 \%$, an average of $390.5 \mathrm{ml}$ of colloids was administered, while in the FO group $<10 \% 159.6 \mathrm{ml}$; having a significant difference in relation to $\mathrm{FO}(\mathrm{p}=0.02)$. See tables $2-3$.

Table 2. Cristaloid solution administration and Fluid Overload.

\begin{tabular}{llll}
\hline Fluid Overload Index & Saline Solution 0,9\% (Vol. ml) & Ringer Lactato Solution (Vol. ml) & Cristaloid tatal Volume Total (Vol. ml) \\
\hline FO $>10 \%$ (Mediana) & 891 & 381,4 & 1272,5 \\
FO $<10 \%$ (Mediana) & 366,6 & 161,1 & 527,8 \\
\hline
\end{tabular}

$\mathrm{p}=0,28$.

Table 3. Colloid solution administration and Fluid Overload.

\begin{tabular}{llll}
\hline Fluid Overload Index & Albumin 5\% (Vol. ml) & Scratch (Vol. ml) & Colloid total volume (Vol. ml) \\
\hline FO $>10 \%$ (Mediana y rangos) & $372,3(0,0-1200)$ & $18,1(0.0-400)$ & $390,5(0.0-1600)$ \\
FO $<10 \%$ (Mediana y rangos) & $119,6(0.0-860)$ & $40(0.0-430)$ & $159,6(0.0-1290)$ \\
\hline
\end{tabular}

$\mathrm{p}=0.02$.

The administration of blood products (transfusion of red blood cells and fresh frozen plasma) administered in $80 \%$ $(n=32)$ of the patients; The red blood cells transfusion (RBCT) was performed in $75 \%(n=30)$ of the cases and 
frozen fresh plasma (FFP) in $52.5 \%(n=21)$. In patients with $\mathrm{FO}>10 \%$ they received an average of $325.7 \mathrm{ml}$ of $\mathrm{RBCT}$ and $289.84 \mathrm{ml}$ of FFP; while patients with $\mathrm{FO}<10 \%$ averaged
$89.86 \mathrm{ml}$ of RBCT and $57.7 \mathrm{ml}$ of FFP, both groups showing statistically significant differences $(p=0.002$ for $\mathrm{RBCT}$ and $\mathrm{p}=0.09$ for FFP). See table 4 .

Table 4. Hemoderivated transfusion and fluid overload.

\begin{tabular}{llll}
\hline Fluid Overload Index & Red Cell Transfusion (Vol. ml) & $\begin{array}{l}\text { Fresh Frozen Plasma Transfusion } \\
\text { (Vol. ml) }\end{array}$ & Total hemoderivated volume (Vol. ml) \\
\hline FO $>10 \%$ (Median and range) & $325,7(0.0-1400)$ & $289,8(0.0-1050)$ & $615,5(0.02450)$ \\
FO $<10 \%$ (Median and range) & $89,8(0.0-264)$ & $57,7(0.0-350)$ & $147,6(0.0-528)$ \\
\hline
\end{tabular}

$\mathrm{p}=0,002$ CGR; $\mathrm{p}=0,09$ PFC.

Regarding the clinical criteria used to guide the administration of fluids during resuscitation, it is observed that: Blood pressure ( $77 \%$ of cases), heart rate $(77 \%)$, hourly diuresis $(60 \%)$, of the which, based on blood pressure and heart rate, did not show significant differences in the study groups $(\mathrm{p}=0.1$ for blood pressure; $\mathrm{p}=0.6$ for heart rate); however, being guided according to hourly urine output was associated with an $\mathrm{FO}>10 \%(\mathrm{p}=0.01)$. See table 5 .

Table 5. Arterial pressure, Cardiac frequency and diuresis oriented fluid administration an Fluid Overload.

\begin{tabular}{|c|c|c|c|c|c|}
\hline \multirow{2}{*}{ Clinical criteria used to oriented fluid therapy } & & & \multicolumn{2}{|c|}{ Fluid Overload Index } & \multirow{2}{*}{$\begin{array}{l}\text { \% percentage (Chi square } \\
\text { test) }\end{array}$} \\
\hline & & & FO $>10 \%$ & FO $<10 \%$ & \\
\hline \multirow{4}{*}{$\begin{array}{l}\text { Starting fluid therapy according to low systolic } \\
\text { blood pressure of the } 50 \text { th percentile }\end{array}$} & \multirow{2}{*}{ Yes } & Count & 19 & 12 & 31 \\
\hline & & $\%$ & $86,4 \%$ & $66,7 \%$ & $77,5 \%(\mathrm{p}=0.1)$ \\
\hline & \multirow{2}{*}{ No } & Count & 3 & 6 & 9 \\
\hline & & $\%$ & $13,6 \%$ & $33,3 \%$ & $22,5 \%$ \\
\hline \multirow{3}{*}{$\begin{array}{l}\text { Starting fluid therapy according to cardiac } \\
\text { frequency above of the } 95 \text { th percentile }\end{array}$} & \multirow{2}{*}{ Yes } & Count & 17 & 14 & 31 \\
\hline & & $\%$ & $77,3 \%$ & $77,8 \%$ & $77,5 \%(\mathrm{p}=0.6)$ \\
\hline & No & $\%$ & $22,7 \%$ & $22,2 \%$ & $22,5 \%$ \\
\hline \multirow{4}{*}{$\begin{array}{l}\text { Starting fluid therapy according to low diuresis } \\
\text { rate below to } 1 \mathrm{ml} / \mathrm{kg} / \mathrm{hr}\end{array}$} & \multirow{2}{*}{ Yes } & Count & 17 & 7 & 24 \\
\hline & & $\%$ & $77,3 \%$ & $38,9 \%$ & $60,0 \%(\mathrm{p}=0.01)$ \\
\hline & \multirow{2}{*}{ No } & Count & 5 & 11 & 16 \\
\hline & & $\%$ & $22,7 \%$ & $61,1 \%$ & $40,0 \%$ \\
\hline
\end{tabular}

Regarding the morbidity and mortality associated with $\mathrm{FO}>10 \%$, those associated with the deterioration of the most frequent organ function and the most frequent metabolic disorder are mentioned, of which renal function and hyperchloremic acidosis showed no differences as regards $\mathrm{FO}>10 \%(\mathrm{p}=0.35$ for impaired renal function and $\mathrm{p}=0.12$ for hyperchloremic acidosis), however, there is an important difference in respiratory function, $\mathrm{PaFiO}_{2}$ in
$\mathrm{FO}>10 \%(\mathrm{p}=0.001)$. See table 6 . The length of hospital stay (LOS) shows no difference in $\mathrm{FO}>10 \%$ and $\mathrm{FO}<10 \%$ group $(\mathrm{p}=0.60)$, in the same way with the PICU stay is observed a mean of 9.4 and 7.2 days in the ISCH groups $>10 \%$ and $<10 \%$ respectively $(\mathrm{p}=0.6)$. Mortality in the $\mathrm{FO}>10 \%$ group was $75 \%$ vs. $25 \%$ in the $\mathrm{FO}<10 \%$ group ( $\mathrm{p}=0.01$ and an OR: $5.5795 \%$ CI 1.4-21.8). See table 7 .

Table 6. Relationship between complication and Fluid Overload $>10 \%$.

\begin{tabular}{lll}
\hline Complications within the first 72 hours of resuscitation & Values \\
\hline & Respiratory function $(\mathrm{PaO} 2 /$ Fio2 $<200)$ & $148,42 \mathrm{media}(\mathrm{p}=0.001)$ \\
$\mathrm{FO}>10 \%$ & Renal function (Creatinine $>1 \mathrm{mg} / \mathrm{dl})$ & $50 \%(\mathrm{p}=0,35)$ \\
& Hiperchloremic acidosis (Delta chloro $>2)$ & $72.7 \%(\mathrm{p}=0,12)$ \\
& PaO2/Fio2 & 238,6 media \\
ISCH $<10 \%$ & Renal fucntion & $38 \%$ \\
& Hiperchloremic acidosis & $50 \%$ \\
\hline
\end{tabular}

Table 7. Relationship between hospitalary outcomes and Fluid Overload $>10 \%$.

\begin{tabular}{llll}
\hline Fluid Overload Index & Lenght of PICU (Days) & Lenght of Stay (Días) & Mortality \\
\hline FO $>10 \%$ (Media) & $9.4(3-23)$ & $17(3-80)$ & $15(75 \%)$ OR=5.57 (IC95 $1.4-21.8)$ \\
FO $<10 \%$ (Media) & $7.2(3-21)$ & $17(7-41)$ & $7(25 \%)$ \\
\hline
\end{tabular}

$p=0.6$ for LOS; $p=0.42$ for Lenght of PICU stay; $p=0.01$ for mortality.

Regarding vasopressor requirements, dopamine was administered in $77 \%(\mathrm{n}=31)$, norepinephrine in $67.5 \%(\mathrm{n}=27)$, dobutamine in $45 \%(n=18)$, adrenaline in $25 \%(n=10)$ of the cases. It was found that there is no relationship between the administration of dopamine, dobutamine and adrenaline with
FO, but it was found association with the administration of norepinephrine $(\mathrm{p}=0.031)$. Regarding the administration of diuretics, this was carried out in $65 \%(n=26)$ of the total study subjects $(\mathrm{n}=40)$, with patients with $\mathrm{FO}>10 \%$ in $59 \%$ $(\mathrm{n}=13)$.$) , and patients with \mathrm{FO}<10 \%$ in $72.2 \%(\mathrm{p}=0.40)$. In 
addition, it is worth mentioning that 4 patients with $\mathrm{FO}>10 \%$ were medicated with continuous infusion furosemide, and 2 patients with ISCH $<10 \%$. It was also observed that $18 \%(n=4)$ of patients with $\mathrm{FO}>10 \%$ received renal replacement therapy $(p=0.012)$. To finalize the analysis of the results of the present study, the determination of the pediatric logistic organ dysfunction (PELOD) is performed, where values of 14 to 25 can be observed in patients with $\mathrm{FO}>10 \%$ with a mean of 22 , while patients with $\mathrm{FO}<10 \%$ values between 10 and 13 with an average of $11.5(\mathrm{p}=0.00)$.

\section{Discussion}

The observed results suggest that an $\mathrm{FO}>10 \%$ is associated with a high probability of mortality, very similar to studies conducted by Naveda E. Omar and collaborators where an association between mortality and $\mathrm{FO}>10 \%$ was found $(\mathrm{p}=0.002)$; Boyd and colleagues demonstrated that a positive balance is associated with higher mortality in children and adults. Vasst and colleagues also indicated that a positive fluid balance at 12 hours and 96 hours was associated with higher mortality in critically ill patients. In the SOAP study, positive balance on the third day after the onset of infection was associated with higher mortality in the PICU in the subgroup of patients with sepsis, among which $40 \%$ had septic shock. [9-16]

The mechanisms by which the increase in FO influence the prognosis of patients with septic shock are still under debate, it is considered that a positive accumulated fluid balance is associated with the development of systemic hypoperfusion, tissue edema, respiratory and renal system failure; Studies carried out by Flori and collaborators concluded that persistently positive balance is deleterious in pediatric patients with acute lung injury, since it causes more days in mechanical ventilation and greater mortality, regardless of the magnitude of the oxygenation failure or severity of organic dysfunction. Along the same lines, Arikan and collaborators demonstrated similar findings, although in this study the time of ventilatory assistance was not considered. [17-20]

In our study, no significant association was observed between renal function impairment and $\mathrm{FO}>10 \%$, but a relationship was observed regarding the use of RRT; similar to findings described by Goldstein and colleagues who observed an association between renal lesion and FO $>10 \%$ and the onset of continuous renal replacement therapy (CRRT); Gillespie et al, showed that an FO $>10 \%$ at the onset of CRRT is independently associated with mortality. These data suggest a survival benefit when CRRT is started early to prevent water overload, in patients with septic shock, renal function impairment and $\mathrm{FO}>10 \%$. Situation that don't be easily allowed in limited resources settings [20-24].

In our study, as in other studies on the administration of crystalloid and colloid solutions in the critical patient (SAFE, CHEST, VISEP, ALBIOS), they have shown that the use of colloids is associated with mortality, coagulopathies and renal failure; unlike Rivers and collaborators on the use of blood products (RBCT, FFP), our study observed in patients transfused a higher mortality and association to $\mathrm{FO}>10 \%$ $(p=0.009)$, with the mention that the transfusion strategy used in our study protocol was liberal and not objective oriented. [25-35] The FEAST study is undoubtedly the most important in that it is the only RCT performed in a population with limited resources, similar to our facilities, and the results suggest a higher mortality in children who received bowling fluids and with positive balance; mainly in view of the associated respiratory and renal morbidity. [36]

\section{Conclusion}

We conclude that the judicious administration of liquids (crystalloids, colloids and blood products) in patients with severe sepsis and septic shock is one of the most useful and first-line hemodynamic treatments; but, if administered liberally, they could produce a water overload with the aforementioned complications, and in a resource limited settings hospital that's means use resources that are scarce, such as assisted ventilation, renal replacement therapy and use of vasoactive drugs.

\section{References}

[1] Reinoso Sarah Alvarez, Sotolongo Efrem Montero, et-al. Factores clínico- epidemiológicos relacionados con sepsis en edades pediátricas. Revista de Ciencias M édicas de Pinar del Río. Volumen 20 No1, Cuba 2016.

[2] Smith Soren H, Perner Anders. Higher vs. lower fluid volume for septic shock: clinical characteristics and outcome in unselected patients in a prospective, multicenter cohort, Critical care, 2016.

[3] Sirvent Josep-M aria, Ferri Cristina, Baró Anna et-al. Fluid balance in sepsis and septic shock as a determining factor of mortality, American Journal of Emergency Medicine, Volumen 33 no 2: 186-189, 2015.

[4] Naveda E. Omar, Naveda F. Andrea, Balance hídrico positivo y alta mortalidad en niños con sepsis grave y choque séptico. Revista Elsevier, Volumen 49 No 3: 71-77, Venezuela 2016.

[5] Karthik Raghunathan, Shaw, Andrew, et - al Association Between the Choice of IV Crystalloid and In-Hospital Mortality Among Critically Ill Adults With Sepsis Critical Care M edicine. Volume 42 No7: p 1585-1591, 2014.

[6] Ingelse Sarah A, Wösten-van Asperen Roelie, et-al. Sindrome de insuficiencia respiratoria aguda pediátrica: $M$ anejo de fluidos en la UCIP, Pediatrics critical care, Paises Bajos 2016.

[7] A. Jonathan. J. Andrew J, et-al, Las estrategias de fluidos y los resultados en pacientes con síndrome de distrés respiratorio agudo, síndrome de respuesta inflamatoria sistémica y la sepsis: un protocolo para una revisión sistemática y meta-análisis, Revista Pub Med Central, 2015.

[8] Henríquez-Palop Fernando, Antón-Pérez Gloria, et-al, La sobrecarga hídrica como biomarcador de insuficiencia cardíaca y fracaso renal agudo, Revista de nefrología, Volumen 33 no2, Madrid 2013. 
[9] Rhodes Andrew, Evans Laura E, Alhazzani Waleed et-al Surviving Sepsis Campaign: International Guidelines for $\mathrm{M}$ anagement of Sepsis and Septic Shock: Intensive Care M ed 2016.

[10] Lira Alena and Pinsky Michael R Choices in fluid type and volume during resuscitation: impact on patient outcomes Annals of Intensive Care Volumen 4: 382014.

[11] Madhusudan Poorman, Kumar Tirupakuzhi Bharath Vijayaraghavan, Cove, Fluid Resuscitation in Sepsis: Reexamining the Paradigm, 2014.

[12] Riley Treavor T, Sanchez Chelsea K, Gauthier-Lewis Mary, Johnson Jessica L, A Concise Review of Colloids for Fluid Resuscitation in Severe Sepsis and Septic Shock, Intensive Care Medicine, 2014.

[13] Baghunathan, Karthik, et-al, what is the ideal crystalloid? Current Opinion in Critical Care, Volume 21, p 309-314. 2015.

[14] Latour-Pérez J. Nuevas recomendaciones sobre la utilización de soluciones de albúmina humana en pacientes con sepsis grave y shock séptico. Una evaluación crítica de la literatura, Revista Elsevier, España 2013.

[15] Castelbón Velao Ricardo Jesús. Albúmina al 4\% vs. Salino $0,9 \%$ en la sepsis grave efectos sobre la mortalidad y sobre los distintos órganos. Revista electrónica de Anestesia; Vol. 3 8696, 2011.

[16] Pietroa Caironi, Langer Thomasb, et-al. Albumin in critically ill patients: the ideal colloid? Revista Einstein volume 13 No3. San Pablo Brasil. 2015.

[17] Arriagada Daniela, Donoso Alejandro, Cruces Pablo, Díaz Franco, Choque séptico: Actualización en la monitorización hemodinámica, Santiago de Chile. 2013.

[18] Gan Heng, Cannesson M axime, Chandler John R, Ansermino $\mathrm{J}$ M ark. Predicting Fluid Responsiveness in Children: A Systematic Review Anales de anestesiología Volumen 6: 8092, 2013.

[19] Monnet Xavier, Teboul Jean-Louis, M arik Paul E. La predicción de la respuesta de fluidos: una actualización. Anales de Cuidados Intensivos Volumen 6, página111 2016.

[20] Nogueira Ávila Maria Olinda, Roca Novis Paulo, et-al. Balance hídrico, angina renal y mortalidad de los pacientes en la unidad de cuidados intensivos, Revista brasileña de nefrología Volumen 36 no 3 Sao Pablo, 2014.

[21] Aguilar Arzápalo M ario Francisco, Escalante Castillo Adrián, Asociación de los niveles elevados de cloro plasmático, en la gravedad y mortalidad de pacientes adultos en la Unidad de Cuidados Intensivos. Revista de la Asociación Mexicana de M edicina Critica y Terapia Intensiva Volumen 29 no 1: 13-21, 2015.
[22] Cecconi Maurizio, Hofer Christoph, et-al, Fluid challenges in intensive care: the FENICE study A global inception cohort study. Intensive Care Medicine, Volumen 1 No 15: 1529$1537,2015$.

[23] Rastegar, Rational Fluid Therapy for Sepsis and Septic Shock; What Do Recent Studies Tell Us?Archives of Iranian Medicine, Volume 18, Number 3: 308-313. 2015.

[24] Finfer Simon, Liu Bette, Taylor C olman, et-al, El uso de fluidos de resucitación en adultos críticamente enfermos: un estudio transversal internacional en 391 unidades de cuidados intensivos. Critical Care. Volumen 21, 2010.

[25] Martensson Johan, Bellomo Rinaldo, Are all fluids bad for the kidney? Critical Care. Volumen 21. p 302-308.2015.

[26] Correa Thiago Domingos, Rocha Leonardo Lima, et-al. Fluid therapy for septic shock resuscitation: which fluid should be used? Biomed, pagina 9, 2014.

[27] Boyd John H Suetrong Bandarn, Pisitsak Chawika, Russell A. James. hipercloremia y aumento moderado de cloruro de suero están asociados con lesión renal aguda en la sepsis severa y shock séptico pacientes, Critical Care Volumen 20, 2016.

[28] Shaw Andrew D, Schermer Carol R. Lobo Dileep N, et-al, Impacto de la composición de los fluidos por vía intravenosa en los resultados en los pacientes con síndrome de respuesta inflamatoria sistémica. Critical Care 2015 Volumen 19. 2015.

[29] Rinaldo Bellomo, Hiroshi Morimatsu, et-al. The effects of saline or albumin resuscitation on acid-base status and serum electrolytes, Critical Care M edicine, Volumen 34, pp 28912897. 2010.

[30] Yates D Hoste E. A, M aitland K, Cuatro fases de la terapia intravenosa de fluidos: un modelo conceptual, Revista brasileña de anestesiología Volumen 113 no 5: 740-747, 2014.

[31] Karakala Nithin, Raghunathan, Shaw D, Intravenous fluids in sepsis, what to use what to avoid: Lest we forget the endothelial glycocalyx in sepsis, Revista Current Opinion Volumen 19: 537-543. 2016.

[32] Garcia de Lorenzo Scores pronósticos y Criterios diagnósticos 2 da edición, Ediciones Ergon, M adrid-España, 2006.

[33] Copana Olmos Raul, Diaz Villalobos Willmer, Cossio Alba Nayda. Déficit de base y depuración del lactato en el paciente pediátrico con sepsis. Gac M ed Bol: 79-82. 2016.

[34] Copana Olmos Raúl Rafael, M elean Camacho Luis Gonzalo. Hiponatremia en pacientes postoperados en el Hospital del Niño Manuel Ascencio Villarroel, Cochabamba, Bolivia. Gac M ed Bol; 37 (1): 20-22. 2014.

[35] Kiguli, RO Opoka, C Engoru, P Olupot-Olupot, SO Akech, Mortality after fluid bolus in African children with severe infection. New England Journal of Medicine 364 (26), 24832495. 2011. 